\title{
Power Relation Reproduction Through Images: A Critical Semiotic Analysis of Language Textbooks
}

\author{
Hajra Yousif Pardesi \\ English language development centre, Mehran University of Engineering and \\ Technology, Jamshoro, Pakistan \\ E-mail: hajrayousif@gmail.com
}

Received: April 5, 2019 Accepted: May 9, 2018 Published: May 17, 2019

doi:10.5296/elr.v5i1.14803 URL: https://doi.org/10.5296/elr.v5i1.14803

\begin{abstract}
Images are in the form of pictures are often used to make books more attractive or more reader-friendly. Images are iconic signs that also convey some meaning. Unlike texts, the messages conveyed by images are less direct and affect human consciousness. This study offers critical analysis of images used in language textbooks from grade 1 to 5 used in government schools of Sindh, Pakistan. The aim of the study is to analyze what and how power relations are maintained and propagated through iconic signs, and how socioeconomic division and nationalist ideology is reproduced by the state through images. The analysis of images shows the portraying of reality in textbooks that legitimizes power relations. Based on Barthe's image theory, the theoretical framework is adapted from Fitsumbirhan (2006) for the critical analysis of the images.
\end{abstract}

Keywords: Power relation, Ideology, images, Hegemony, Nationalization, Visual representations, Mystification, Semiotic analysis

\section{Introduction}

Power is the ability to influence or control the behavior of people. Power cannot be reduced to institutions and a group. Foucault (1980) maintains that, "power is everywhere, not because it embraces everything, but because it comes from everywhere. It does not have any shape, but it occurs in various forms at different levels." (p. 93). He further elaborates that, power must be understood as the multiplicity of force relations that exist as a system of set of relationships, inherent in the sphere in which they operate and constitute their own organization by transforming, strengthening or reversing through unabating struggles and confrontations. Power is the relationship between people in a society and how they define themselves in regard to these relationships. The knowledge and regimes of the truth in a 
society are a product of the strategies that are socio-economically motivated. Power is intimately connected to language, as it is exercised through forming a discourse which refers to the use of language that has meaning and produces some effect. This dominant discourse enacts activities and give identities to the people in a society.

Educational institutes are one of the major sites which reinforce such discourse (only) that reproduces the established power relations in a society, and which in turn shapes the structure of education system accordingly. Althusser (1970) observes that, "the school constitutes the dominant ideological state apparatus, the apparatus, playing a determinant part in the reproduction of the relation of the production of a mode of production threatened in its existence by the world class struggle." (p. 157). The primary role of education in any country should be an infusion of wisdom and knowledge. In this regard, Freire (1970) is of the opinion that, the function of Education can either be as a tool to integrate young generation into present logic system in order to bring conformity or to practice freedom in which people are aware of their significant role they can play in the transformation of the world, which can be done by generating critical consciousness and creativity to cope with ever transforming social realities.

In the contemporary world, the social control lies in the consent of the population, rather than force which is abeyance for the situations of emergency. The everyday control is implied through the fabric of rules, values, and regulations that are passed from generation to generation by the state patron institutions in the society. In Pakistani society, education system mainly plays doctrinal and hegemonic roles in various ways (Nayyar \& Salim, 2003). Gramsci (1999) defines hegemony as permeation of a system of values, beliefs, attitudes and morality that supports the status quo in power relations, that are internalized through the process of socialization by the governed who then becomes the part of 'common sense' in a way that the ruler's culture and morality appear as logical and natural in the society. Education system exposes students to knowledge that is biased to the dominant class and reproduction of that knowledge is the criteria of being successful. Schools are the indoctrination sites which promote false information and one-sided knowledge. With increase in level of education, the ability of asking questions, being curious, challenging and hence being critical declines. Reality is never specific, static, unambiguous, linear and contradictory but our education system makes us to think so.

The knowledge, curriculum and pedagogy are determined by the one having power and reflect their motives. It performs social function of reproducing culture of dominant group that is socio-economically and politically powerful. Textbooks can be regarded as the primary source of input in the learning process and are designed with the same motives. Apple (2000, p. 181) rightly observes that, "it is naive to think of the school curriculum as neutral knowledge. Rather, what counts as legitimate knowledge is the result of complex power relations and struggles among identifiable class, race, gender, and religious groups." In real, it imports lies, false information and selective knowledge in young generation, underlining political purposes.

Textbooks are the major source that organizes the knowledge system of society and 


\section{$\triangle$ Macrothink}

consolidates the dominant discourse. Its content is the knowledge that is acceptable and regarded as common sense, which excludes the information that is taboo despite of its truthfulness. The truth is something which is supported materially by a whole range of practices and institutions: universities, government departments, publishing houses, scientific bodies and so on. All of these institutions work to exclude the statements which they characterize as false and they keep in circulation of those statements which they characterize as true. So, one can discern that in order to control a society, one has to control the production and regulation of discourse (Foucault, 1981). Textbooks are the first exposure of students to learning and knowledge. Combined with pedagogical practices and assessment criteria, the use of the textbooks cannot be denied whether by teachers or by students. The reproduction of culture accompanied with pedagogic action results in the reproduction of the whole social system or social formation (Bourdieu \& Passeron, 1990). In this study, selected images are specifically from textbooks that are used in primary level education. The primary education is the most essential period in a child's life, which is also a crucial in a child's cognitive development too. Whether it makes students passive receiver of information or train them to question, depends upon the state policy who have authority over the education system. At this stage, a student act as empty vessel that would incorporate the input, which he/she is receiving, partly because of power relation between teacher and students and partly because of misconception about the idea of educational institute as a site of truthfulness. Moreover, education is socializing process as it constructs the student's behavior, morality, believing, perceptions, and attitude. It exercises disciplinary power that "trains" and "make individuals" (Foucault, 1984, p. 188).

The focus of this study is on the images, used in textbooks. Images are frequently occurring objects that can easily be observed around us: in magazines, newspapers, television, books, articles, banners, posters and internet sites. Almost every written text includes some kind of pictures or iconic signs. This frequent use of images shows the important role they play in communications because images are language which has construct meaning and are used for communication. According to Saussure (1986), "Language is a system of signs. A linguistics sign is a double entity, one formed by the association of two terms: signified: the concept and signifier: sound-image" (p. 66). The relationship between signifier and signified is not logical but conventional. The makeup of an image: iconic signs, is in the same way where signifier is an explicit imitation of signified, but no logical relation is necessary (Saussure, 1986; Barthes, 1977). The trait of imitation makes them as naturalized entities: parallel to the real world, but iconic signs are mirror reflection of the world in their primary meanings; only. According to Barthes (1964), the images have two levels of meanings; the denotational and the connotation. He further adds that, "the denoted image naturalizes the symbolic message, it innocent the semantic artifice of connotation." (p. 45) The choice of images in any lesson is affected by a number of factors in the context of its production and in the context of its reception. This study aims to find the use of images in the textbooks at primary school level, and how they work to maintain power relations in the society.

The central argument of the present study is on the politics of textbooks generation which is an act of state formation by reproducing power relations. These textbooks are used as vital 


\section{N Macrothink}

tools that naturalize the socio-economic discrimination in our society. Their function is not in favor of the people, but in favor of the dominant power group. Bourdieu (1990) is of the opinion that the ruling class reinforces their rule idea which legitimize them, by concealing their basis in the economic and political power of the ruling class. The schooling system inculcates the information that legitimizes radical nationalism, class division, and mystifies reality in our society. This indoctrination from the very beginning regulates the process of identity formation of the student. The imagined identities given in textbooks are the idealized and authorized that must be followed by every student. This work will help to understand the biased nature of images that are used in textbooks under analysis and what messages are conveyed by their decoding and their possible impact on targeted audience i.e. students.

\subsection{Aims and Objectives}

- To identify the hidden ideologies underlying the images used in language textbooks of primary level in government sector schools in Sindh, Pakistan.

- To explore the possible impact of ideologically-loaded images on L2 learners.

\subsection{Research Questions}

- What hidden ideologies underlie the images in Sindhi language textbooks at a primary level in government public sector schools, Sindh?

- In what ways do the hidden ideologies of the images affect learners?

\section{Literature Review}

Education is the primary means of achieving literacy and books are the major sources that organize the knowledge system of society. Textbooks portray the canon of truthfulness and help recreate major reference point for what knowledge, culture, belief and morality is. Generally, Culture is seen as a set of shared norms and practices exercised by people in a social community. But culture formation in its real sense results into division, every cultural form signifies its particular class. Enforcing one cultural form over the other results in class dominance. Culture functions as producer and reproducer of value system and power relations. Raymond William (cited in Apple 2000, p. 182) claims that, "Textbooks have always been a part of selective tradition: someone's tradition, someone's selection, someone's vision of legitimate knowledge and culture, one that in the process of enfranchising one group's cultural capital disenfranchises another's." Textbooks are hegemonic in nature as it includes the ideas and knowledge of the culture of the dominant class. The ideology that stands behind this is to combine a commitment to determine or recreate traditional family concepts, gender roles, traditional value, national culture, class division and literal religiosity in the population. In short, it resists to generate critical thinking, but on the contrary, it makes perceive and accept the thing as they are. The important decisions regarding the official knowledge are taken by powerful group of people, incorporate that group's vision of legitimate knowledge.

Luke asserts that, "the processes of cultural incorporation are dynamic, reflecting both continuities and contradictions of that dominant culture and the continual remaking 
and re-legitimation of that culture's plausibility system." (cited in Apple 2000, p. 187) Apple further elaborates that, curricula are not imposed rather they are the product of intense conflict, negotiation, and attempts at rebuilding the hegemonic control of textbooks by actually incorporating the knowledge and perspective of the less powerful under the umbrella of the discourse of dominant groups. Dominance is partly maintained through compromises and mentioning. (1979, pp. 63-64) This inclusion is only restricted to those elements that are in association with the values of powerful group and are not in contradiction with them, and with the influence of the latter the former reflects the essence of conservatism and backwardness. As a repercussion, it generates alienation and degradation of subordinate culture and justifies the sophistication of dominant culture taught in classrooms that is worth learning and living with.

Crawford (2000) justifies the biased nature of textbooks by quoting a number of studies from various writers which clarifies that the social changes in societies is often regulated by ideological changes made in curriculum. These changes are in support of the ideology of the dominant group of that society. He stated that,

"School textbooks are one vehicle through which attempts are made to disseminate and reinforce those dominant cultural forms, furthermore, he said that, range of evidence suggests strongly that there is a need to engage in the critical analysis of textbook production and to uncover the ideological and political forces at work in their manufacture." (2000, p. 4).

Textbook evaluation needs an up to date and fresh contribution in this area. Apple (2004) calls it "ideological hegemony", which is an act of ruling the people in a subtle way by saturating the consciousness of students. These actions are done by the class having economic and political power which answers to their need of maintaining the status quo. He also said that, "the control is vested in the constitutive principles, codes, and especially the common-sense consciousness and practices underlying our lives, as well as by overt economic division and manipulation." (2004, p. 4) The education system, including textbooks operates on the idea of hegemony as the young generation is made to believe in what is said to them in a subtle way. The process of inculcating the selective knowledge is done in such a way that there remains a very minute, chance of resisting the stated things. Because neither the content nor the exercises being given at the end of every exercise are devised to develop analytical skill in students. "We have this enormous gap in our educational system, where young people learn about the ideals of liberty and democracy, but they don't learn about the reality of a class society in which a very small number of wealthy people dominate the society" (Howard, 2005, p. 30). The reproduction of culture is largely regulated through pedagogic action that plays a significant role in the reproduction of the whole social system (or social formation). The pedagogic practices in schools like rote learning, repetition, blindly following the teacher, kills their critical sense and their logic of questioning for example, if a child is made to learn everything by repeating in exactly the same way or either he/she will be unsuccessful, then it is making them to accept thing as they are despite of the differences between their real life and idealized life portrayed in textbooks.

Education is the basic source of knowledge and economic development for people in every 
society, whereas, in Pakistani society, the function of educational institutes is not only to provide knowledge. Its aim is stated by Nayyar and Salim (2005) as,

"Governments everywhere use education to further the process of nation building. In Pakistan, through the teaching of history, language and social sciences, children are taught what the state and society believe should be part of their shared identity and perspective for understanding the world." (p. 2)

Identities and value systems of children are shaped by the school textbooks and curricula of these subjects, that are being designed and approved by National curriculum wing and published by the provincial board. These institutions are the prime decision-making authorities regarding the content in educational material and, what happens inside the classroom across the country. The culture which is promoted through the education system is of the group that has economic and political domination. The textbook controversy in Pakistan has been highlighted by many scholars. Nayyar and Salim (2005) further analyzed that, Pakistani curricula shows that it incorporates: inaccurate facts, omissions of necessary events, concepts and material, insensitivity to religious diversity, incitement to militancy and violence, discriminatory perspective toward women, other nations and religious minorities, glorification of war, and outdated and incoherent pedagogical practices. These strategies contribute to biased nature of textbooks in Pakistan and the possible hegemonic effect it could lead to. In this respect Zaidi (2010, p. 1) rightly observes that, "distortion of educational policy should logically have the ability to disrupt the thought processes of the students." In order to change or inculcate a particular type of thinking in the upcoming generation, one must control the production of textbooks first. The Pakistani nationalism is promoted in history textbooks by emphasizing shared national symbols like national heroes, culture and common ancestors. Pakistani nation is defined by highlighting its difference from other nations, particularly Indian nation' (Yaqian, 2012). Such definition forms are the base for identity formation of the students. They characterize themselves according to the nations defined in textbooks, hence allocating identities to the upcoming generations. In reality, it is designed primarily to domesticate and create obedient workers that are to be fitted in existing slots present for them in social structure, but not to change that societal structure. This center argument of this paper would be in favor of this biasness of education that our children are receiving, and how textbooks are used as the main tool for exercising hegemony in our society. The culture that is promoted by schools is of the dominant class that has power. This makes the culture of dominant class as superior to the other cultures in the same society.

The case of textbook controversy is not only in Pakistan, but Indian nation is also suffering from the same issues in their curriculum. In recent years, the textbooks are being redevised and rewritten on the guidelines from the present ruling party BJP government in India. Krishnan (2015) says that, "his department is already chalking out a roadmap where lessons from epic Hindu literature such as the Mahabharat, Ramayana and Bhagavad Gita would soon be taught in schools and colleges to rid the country of 'cultural pollution' and inculcate 'values' among young minds." ${ }^{25}$ This new curriculum includes exclusion of facts, one sided narration of events, religious sectarianism, and distortion of history, gender discrimination, lies and nationalist extremism in young generations. 'Controversies of the BJP government 
are tactfully ignored in the new books. Gandhi's assassination and the 2002 Gujarat riots aren't mentioned anywhere. Also, the initiatives talked about in the textbooks highlight only the positive aspects, lacking any critical assessment; demonetisation is defined as an action against corruption but hides the negative impacts that the decision has had on the Indian economy and people. This is a clear example of 'manufacturing consent' (Shruti 2017). They are propagating the party's Hindutva ideology through alterations in the school syllabus.

In the educational process, not only the pedagogical practices and content is devastating, but the visual elements like images, as signs, are also ideologically loaded. Semiotic analysis treats them as cultural codes and discloses the connotative meaning working beyond its denotative meaning in its context of use. Semiology allows the ability to attribute meanings to objects in regard to the entire social sphere (Kukurt, 2016). The students consider these visual objects as mere images that are colorful and attractive representations, with no implicit meaning. From critical education's perspective, all neutral appearing objects, elements, styles, physical forms, pictures, etc, used in the educational processes incorporate values that reproduce the ideologies and myths of power. It is an issue that needed to be explored and incorporated into the study, as symbolic representation also contributes to the formation of the dominant discourse, to which it reflects. According to Kukurt (2016), "A semiological analysis can help to understand the visual elements in the educational process and the images and associations they create that serve as mediators for the "heroic" transfer of some values that belong to a political power." (p. 2169).

There is ample research done on the political nature of the textbook (see, Nayyar \& Salim 2003, Zaidi, 2010, Yaqian, 2012, Jat, Pathan, \& Shah 2018). How certain groups have been portrayed in textbooks has been a recurrent topic in research studies. Visual representations of reality can be an important indicator of how the power relations in a given society. A study by Fitsumbirhan (2006) in Ethiopian context elicits that, "the stereotypical portrayal of the powerful and the powerless in newspaper photographs can possibly influence on the way people think and reflect about power relations in society." (p. 2) The frequency of the occurrence of photographs of ordinary people vs high status people and the way they are portrayed reflects the socioeconomic and political conditions in Ethiopia. With the eye-catching effect of images on students, it is a significant area that can indicate power relations prevailing in any society. However, in Pakistani context, the understanding and reception of visual communication has not been much studied. Using visual analysis from a semiotic perspective, this study is an effort to fill this research gap. It highlights the role of images in contributing political nature to textbooks.

\section{Research Methodology}

The purpose of this study is to explore the representation of social power relations in images used in textbooks through semiotic analysis. The study is conducted using a qualitative method. The analysis of data is conducted by semiotic approach to image evaluation. Qualitative Research is primarily exploratory research. It involves exploring a problem and gaining an understanding of the underlying reasons, opinions, and motivations. In qualitative inquiry, the intent is not to generalize to a population, but to develop an in-depth exploration 
of a central phenomenon. Thus, to best understand this phenomenon, the qualitative researcher purposefully or intentionally selects individuals and sites" (Creswell, 2012).

\subsection{Semiotics as Analytical Framework}

Semiotic analysis of each image is done to answer the research questions. At first the samples are coded with four coding scales: The overall coverage, the subjects in images, appearance of image, portrayal. These coding scales are used to identify the formation of denotative and connotative meaning in each image. The researcher has adopted these two coding categories from a similar study focused on power relation identification from the front-page photographs in the newspaper in the Ethiopian context (Fitsumbirhan, 2006). The coding instruments used to interpret the meaning of the images are in the coding table below:

Table 1. Semiotic instruments used to interpret images (Fitsumbirhan, 2006)

Denotation

It is the first order of signification. In image, it is a literal meaning or logical representation of the object it represents (visually identical in case of iconic sign).

Connotative

It is the second order signification in which denotative sign act as a signifier and an additional signified is attached to it: giving more than one meaning of a sign. The connotation is not a logical, but an additional association, formed in relation to culture, ideology or the society of the reader. Connotative meaning develops as a result of interaction between a sign and the feelings or emotions of the reader and the values of their culture in a context.

The selected images are analyzed on the basis of these three types of messages: Denotation, and Connotation message. "The image as a nonverbal language makes connotation, it is like an interior negotiation with the viewer and these connotations are heavily influenced by the cultural and mythic factors" (Bouzida, 2014, p. 1004). In this semiological analysis of iconic signs, the emphasis is giving more on connotation meaning of non-verbal sign because of its ideological and mythical factors. This study is content analysis, which is an open-ended process and is subjective to the researcher. It is important to point out here that the semiotic reader plays a very important role in the interpretation of meanings behind the visual elements as these are open to many interpretations. But the interpretations are specific to the discourse context of its society.

\subsection{Data Collection}

The tools for data collection are language textbooks. The language textbooks: Sindhi, and, English, that are used in primary level education from class 1 to 5 are being selected for the study. These textbooks are published by Sindh textbook board and are used in government 


\section{Al Macrothink Institute ${ }^{\mathrm{TM}}$}

sector schools in Sindh province of Pakistan. These textbooks are usually designed and approved by national curriculum wing and published by the Sindh textbook board. Purposive sampling is used to collect the images from textbooks. The analyzed issue was of the publication year 2010 to recent editions (2017).

\subsection{Data Analysis Procedure}

Each image is analyzed as a whole and complete source of conveying meaning(s). Every image is considered as consisting of a number of signs standing in relationship with each other, giving a coherent message; as a whole. The researcher has adopted coding instruments from the study of Fitsumbirhan (2006). This study is more concerned with identifying the connotative meaning attached to the coded image, which are hypothesized to regenerate power relations in society. First, the signs are coded into coding categories and then, the critical semiotic approach is used for the descriptive analysis of the data.

\section{Findings and Discussion (Historical Facts)}

With the inception of Pakistan, the newly born state was laden with many conflicts and controversies. These conflicts were based on religion, ethnicity, cultures which shows the inability of the state to handle the diversity within the state. The nature of these issues signifies the Pakistan's struggle for an identity. As a repercussion of these insurgencies, there was an instant urge for the promotion of idea of Pakistani nationalism, which could act as an anti-resistant firewall from these conflicts. This results in the formation of elements of homogenization and uniformity to reduce one of the major conflicts which was of ethnic diversity. So, the idea that despite their differences in culture, traditions, norms, languages and ethnicity, we are Pakistani, functions as social integration.

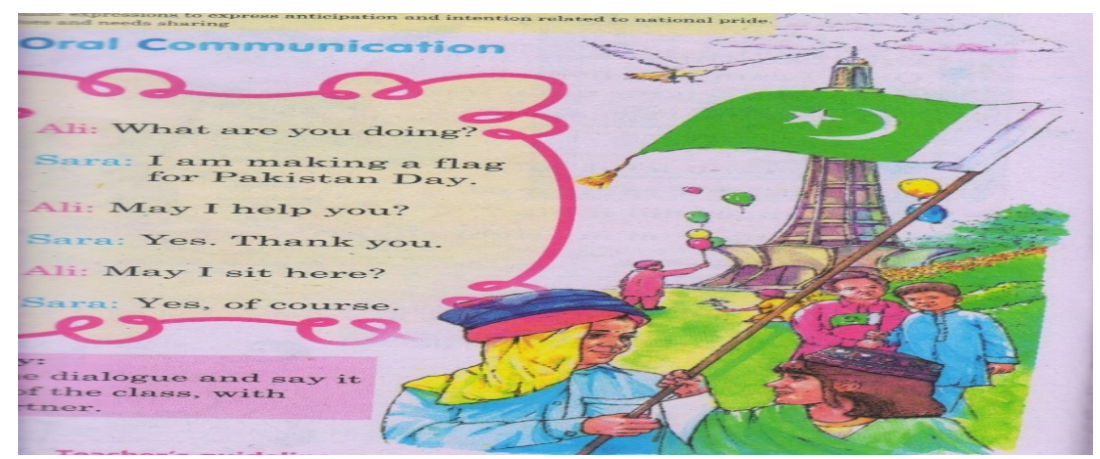

Image 1. My English book 2, unit 6: patriotism page 46

Image 1 denotes a boy (wearing Balochi turban) and a girl (wearing traditional Sindhi cap) holding the flag of Pakistan, are standing beneath that flag with Minar-e-Pakistan at the background. This posture reflects the idea of nationalism. Its connotative meaning can be read as promoting the idea of homogenization by act of forced inclusion of the youth, which indirectly determines that despite of the differences among the people living in Pakistan, the 


\section{Macrothink}

only identity they have is "Pakistani". "Pakistani national identity and nationalism is explicitly instructed through schools" (Jat. A, R, et al 2018, p. 28) Minar-e-Pakistan can be decoded as a symbol of the creation of Pakistan and the complete white background is perceived as a sign of peace in our culture. To sum up, it conveys the message of harmonious integration of all citizens under the label of "Pakistan as a single unified nation" at the cost of ethnic cleansing, which has been indirectly justified. The national integration process requires certain strategies for achievement. According to Kazi (1994) There are two public policy strategies for the achievement of national unification: the assimilation process in which distinctive cultural traits of cultures of minorities are eliminated by submerging them into the national culture, usually that of the dominant group. The unit-in diversity process: in which national loyalty is established without eliminating sub ordinate cultures. In Pakistan, nationalism is greatly achieved by assimilation process.

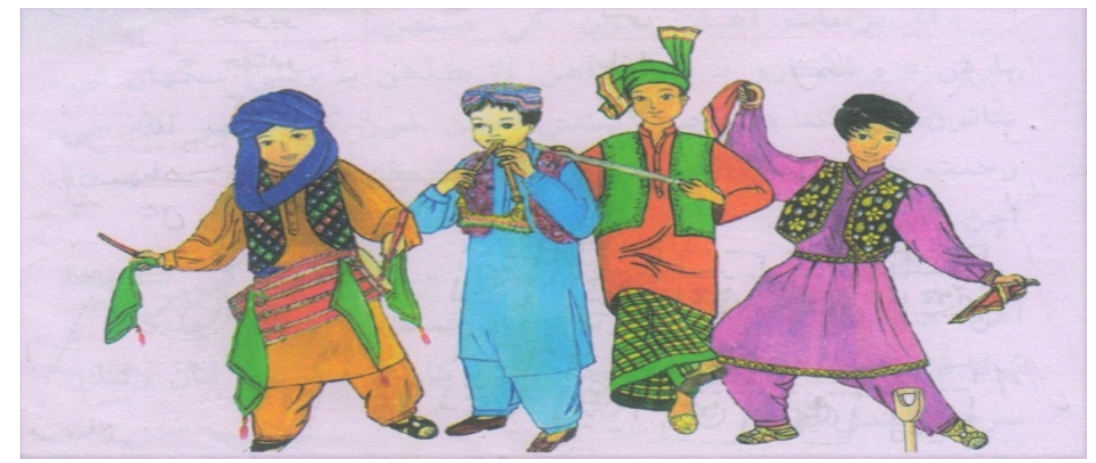

Image 2. Sindhi language book 2, Lesson8: Aazadi jo dihn page 21

Image 2 denotes 4 boys in a dance posture, with smiling faces which signifies the happiness on the Independence Day of Pakistan. The four boys portray 4 major ethic identities in Pakistan: Sindhi, Punjabi, Balochi and Pashtun, who are in their cultural dresses and dancing on their traditional music. The text that follows an image function as anchorage: "the text directs the reader through the signified of the image, causing him to avoid some and receive others; by means of an often-subtle dispatching, it remote-controls him towards a meaning chosen in advance" (Barthes, 1964, p. 45). The image 2 is followed by lines that could be translated as: 'There are four provinces in Pakistan: Sindh, Punjab, Khyber Pakhtunkhwa and Baluchistan. All the people living in Pakistan are in love with each other.' The image combined with text symbolizes 4 provinces with 4 major cultures in Pakistan, which is ultimate and deliberate exclusion of the people belonging to other sub ordinate cultures like Saraiki, Brahui, Kalash, Burusho, Hindkowans, Pathans of Punjab, Afghans in Pakistan, Dardic, Shina, Balti, Awan, Siddi, Wakhi, Parsi, Baloch, Jat, Arain, and Dravidian. People who speak these languages are also residing in Pakistan. The second line of the text and smiling faces can have a connotation meaning of promotion of the idea of unity through deliberate homogenization by skipping the inter-ethnic issues in Pakistan. It also reflects the reduction of culture to material things, as the text also does not specify anything about these 


\section{MInstitute Macrothink $^{\text {Int }}$}

cultures.

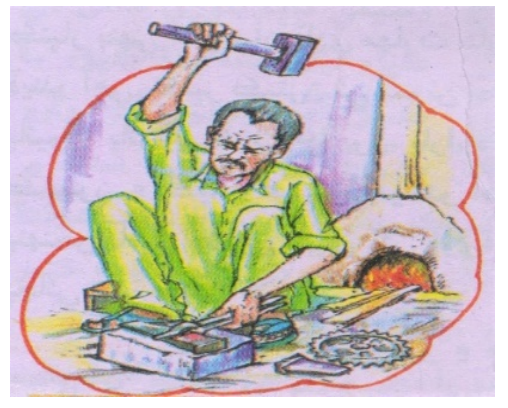

Image 3a. Lohar (Iron man)

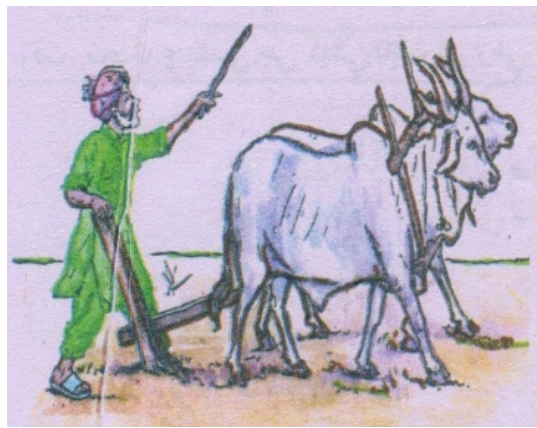

Image 3c. Harri (Farmer)

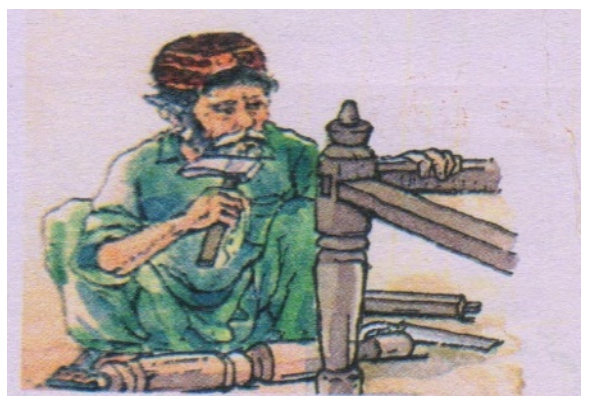

Image 3b. Wadho (Carpenter)

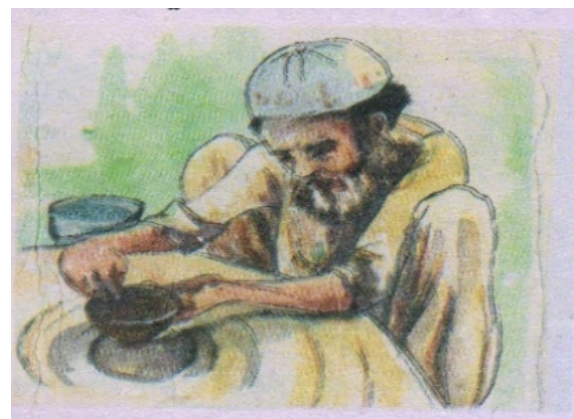

Image 3d. Kumbhar (Pottery maker)

Source: Image 7: Sindhi language book 5

According to Apple (2000) textbooks signify, through their content and form, particular constructions of reality, through ways of selecting and organizing the knowledge from that vast universe of possible knowledge. This collage of 4 images is taken from a lesson: "work and art". The choice of these images directly tells the importance given to these professions like Lohar (Iron man) 3a, Wadho (Carpenter) 3b, Harri (Farmer) 3c, and Kumbhar (Pottery maker) $3 d$. It is an attempt of producing division of labor. As these books are designed to be used in Government sector schools where students belong to the lower-class families, the choice of images indirectly justifies class division and training students for similar future. By highlighting only village life and jobs, the possibilities of lower-class people to recognize their potential to progress towards the middle and upper class is shunt. It also naturalizes the prevailing conditions in our society that is as organized by class division. In comparison with some images of professions in textbooks used in private schools, there seems to be an explicit difference between them. The profession given in private school textbooks is the one is of middle-class people like, doctor, engineer, nurse, and officer etc., given in Appendix 2. This follows the idea of Hidden curriculum: training the students for the similar future (Apple, 2004). As today's vocational schools are training institutes “....in which the pupil's destiny 


\section{Macrothink}

and future activity are determined in advance" and aims at "development of the capacity for working manually (technically, industrially) and development of the capacities required for intellectual work" (Gramsci 1999, p. 166).

"Self-deprecation is another characteristic of the oppressed, which derives from their internalization of the opinion of the oppressors hold of them" (Friere, 1967, p. 67). The above image shows the natives portrayed as backward, old, traditional and regressive. In a sense, shows their lack of knowledge, futility and incapability of learning anything which is a strategy to persuade them with their unworthiness. This would possibly result in their passivity before the prescribed knowledge being instill in them.

The act of imposing laws and regulation is not the only way to make the people obey the state's command. These rules themselves must be justified for their implementation in population. The constitution of any country is the last word for its citizens which define the limits of their actions within that state. Even our human right of liberty is subject to the laws being imposed by the state. These laws have been legitimized by the state, and mostly this process's main tenet is depicting state as sole responsible and caretaker of its residents in textbooks. It is made to consider as protector and concerned for the well-being of the people. This consent is achieved in positive way: showing them what the state is doing or has done for its citizen or by negative way: injecting culture of fear in their minds.
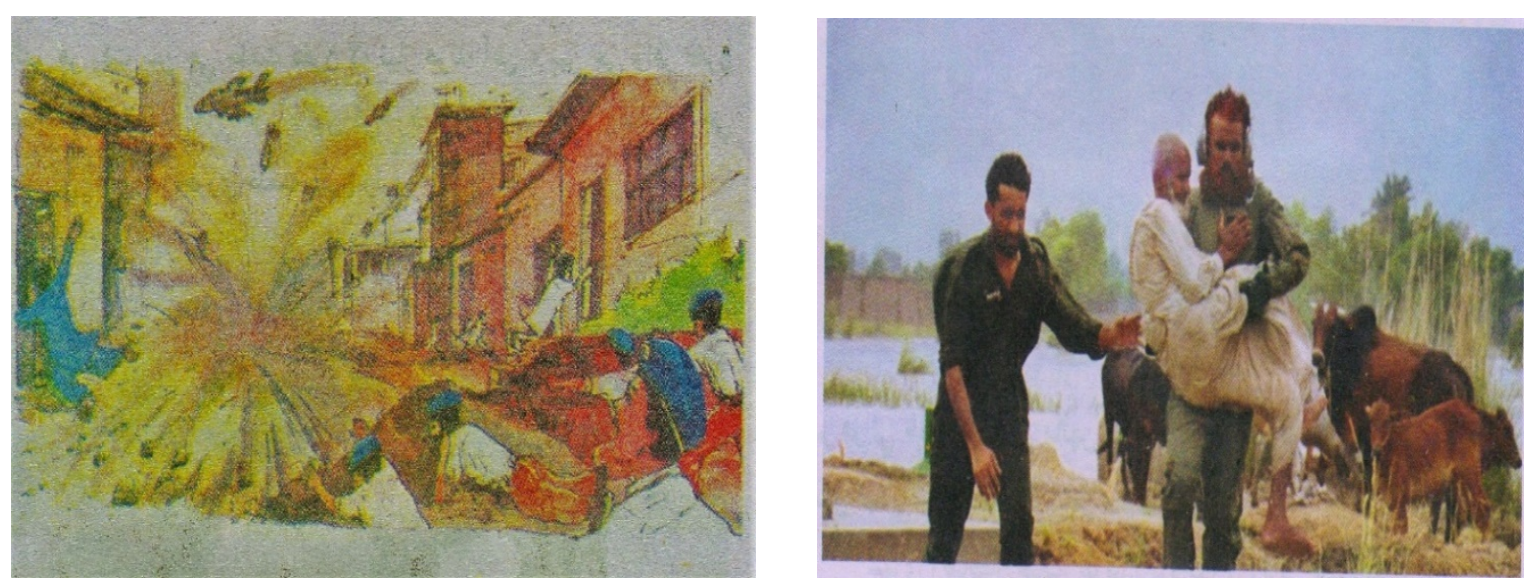

Image 4. Sindhi Language Book 5, lesson 12, Shairi Razakari, page 65, 66

The image at left visualizes a bomb attack in a city and the one at right side reflect the aftermath situation of a bomb blast. In terms of denotation, the image illustrates state as protector of the citizen and government is responsible for security and safety. Its connotative meaning symbolizes possible threats which could develop a fear in citizen's mind. The first image presents a destructive scenario. The second image is not much dreadful: the state is portrayed as the one providing a helping hand to injured citizens. It could be an act of making the citizens to surrender or compromise with the state in the name of security, defense and sometimes progress. This deliberate attempt is regarded by Noam Chomsky (1996) as 


\section{Ml Macrothink}

developing "Culture of Fear". He elaborates that, the imposition of silence and spread of fear is necessary in countries where there is highest inequality in the world. It is achieved in the name of maintaining peace and order. To impose silence on the internal enemy is necessary in the democratatorships. It makes the students to be supportive of the establishment and be against everyone that is regarded as wrong by the state.

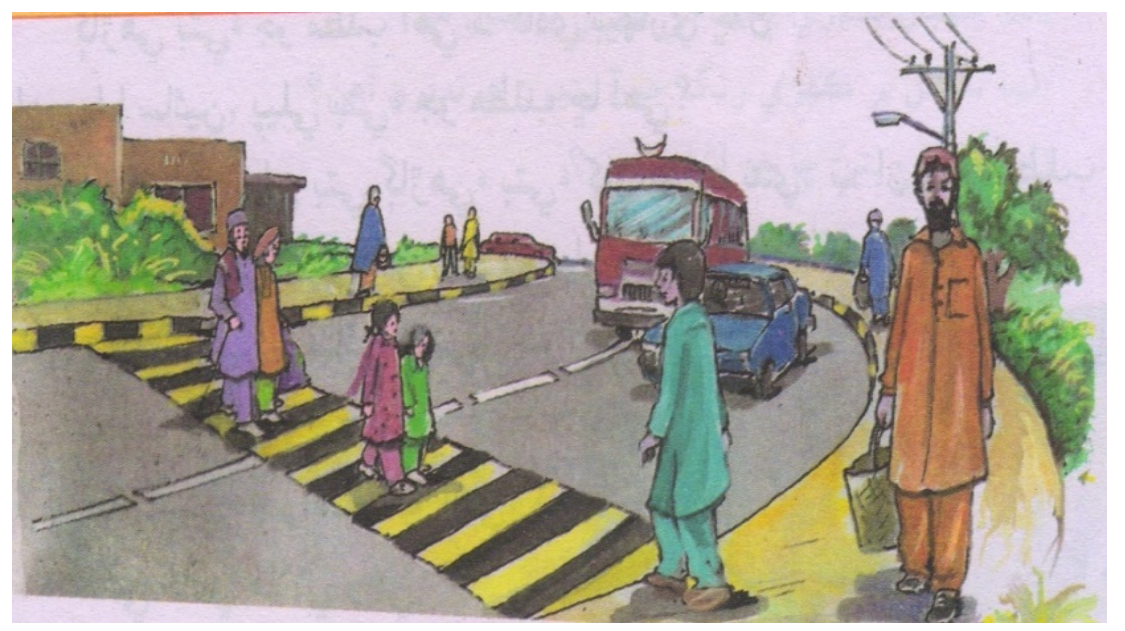

Image 5. Sindhi language book 3 lesson 8: Rules for walking on road

This picture denotes a very positive, organized, clean, protective, and responsible image of the state, but hides the state's mismanagement, responsibility and present condition of our infrastructure. Traffic signal, Zebra crossing, and footpaths are hardly part of infrastructure in our society. According to a 2014 report by the World Health Organization, 30,310 is the average number of people died in road accidents each year in Pakistan, and by 2030, road accidents will become the 5th major cause of deaths. Reasons: poor conditions of roads, unskilled drivers, illegal issuance of license. The text following this image say: One motorbike rider adult is breaking the traffic signal and end up in a deadly accident. Reading the sign in relation to linguistics message can be connoted as training the citizens to follow the rules of the state which are portrayed to be beneficial for the citizens. It is a subtle way of producing fear by giving the possible repercussion (something dreadful like road accident) of not following the state's rules. In broader sense, it indirectly legitimizes all the rules and laws that are imposed by the state, that should be accepted without any questions. The law renders a safe zone for all the citizens and state is implementing them to for a good cause.

The textbooks include such elements, that visualize an ideal society represents the society where everything is perfect and ideal. Howard Zinn (2016) is of the opinion that, in democratic society, schools give people the ideals about their society in which they live. They resist giving the information that shows the violation of these ideals in reality and snatch them of their analytical tools which can help them to have critical perspective of society and to unveil the discrepancy there is between these ideals and the reality. 


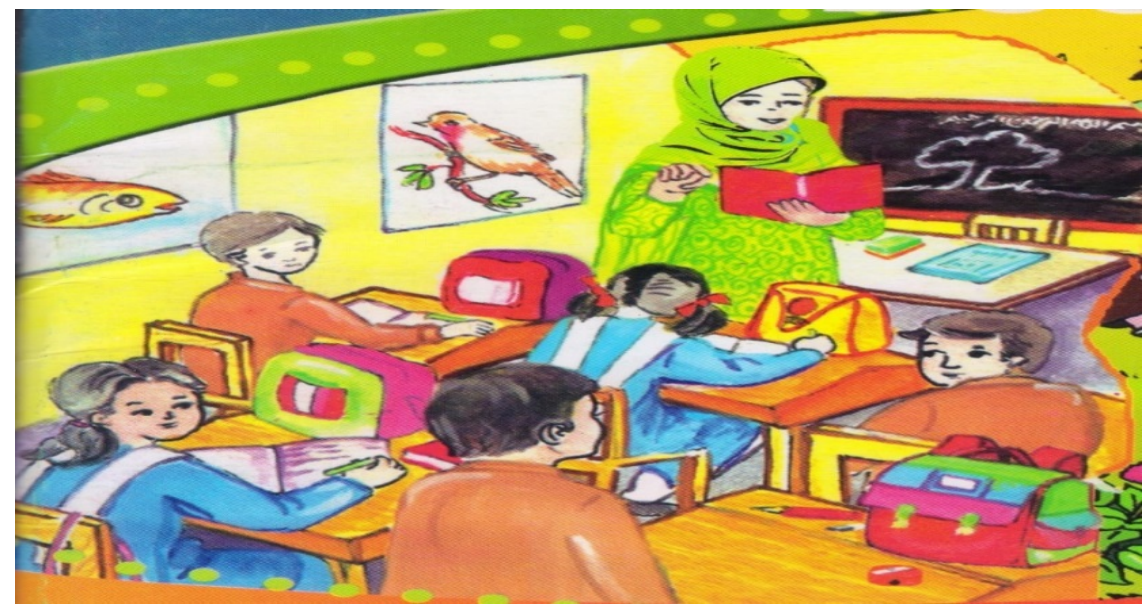

Image 6. English language book 5, unit 4 truthfulness, page 58

The image denotes a very organized, developed and colorful environment of a classroom. Every student wearing clean and tidy clothes seems to be contented and happy. They have their bags, books, stationary and lunch boxes. One picture of school that is representing all the schools in Pakistan symbolizes an initiative of justifying the injustice and class division prevailing in our society. According to the Bureau of Statistics Planning and Development Department, Government of Sindh (2017), "there is a 45,447- total number of schools, out of which 7,120 schools have shelter less buildings in Sindh Province. There are many schools without the most basic necessities as can be seen in Table 2 .

Table 2. The basic facilities provided in schools in Sindh province

\begin{tabular}{lll}
\hline Basic facilities & Number of schools with & Number of schools without \\
\hline Electricity: & 16,893 & 28,554 \\
Drinkable water: & 22,514 & 22,933 \\
Boundary walls: & 26,655 & 18,792 \\
\hline
\end{tabular}

Source: Bureau of Statistics Planning and Development Department, Government of Sindh (2017) report.

In comparing this image with a photograph of a government school child in the Charchai village (Appendix 1) one can see a huge difference. In that picture, the child is wearing untidy clothes, having no bag and lunch box, his face reflects hunger, and poverty. "The school system varies with class division where elite class schools designed to produce rulers and lower-class devise to produce the ruled ones. Gramsci pointed out that "The fundamental division into classical and vocational (professional) schools was a rational formula: the vocational school for the instrumental classes, the classical school for the dominant classes and the intellectuals". (1999, p. 165) With reference to this knowledge, the image can be 


\section{Ml Macrothink}

connoted as an act of making the students believe that there is a perfect happy life that everyone is living outside the classroom and they must strive to maintain this perfection. The education system will help them to achieve these ideals. Hence, it is an indirect legitimization of the hegemonic function of the education system in Pakistani society.

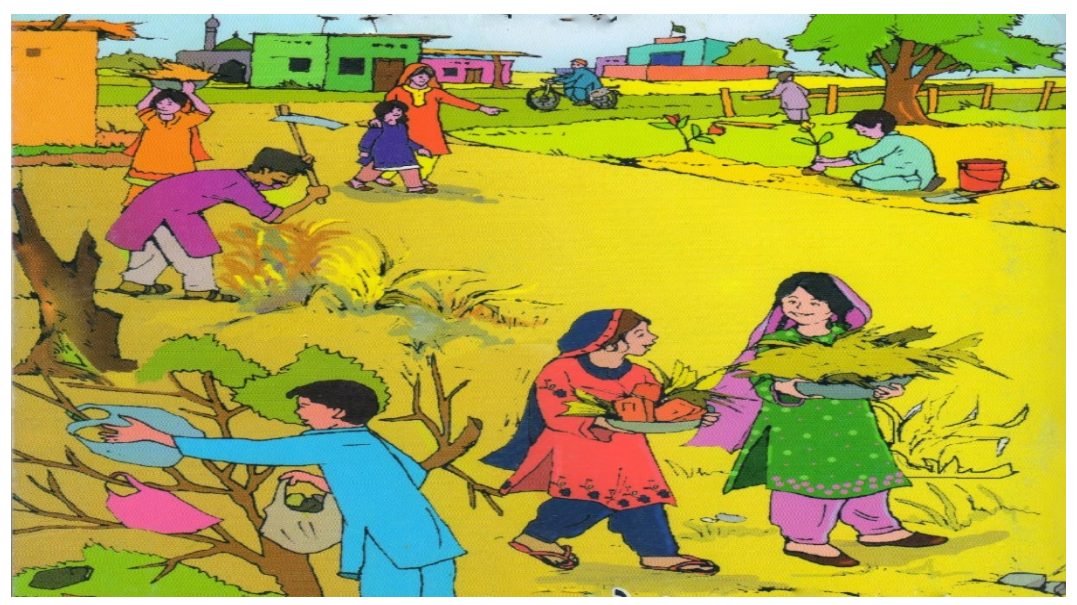

Image 7. Sindhi language book, lesson: lesson my village

The denotative meaning of this image is beautiful and colorful scenario of a village life where everyone is busy in their life. People engage in their daily life activities and seem to be happy. This image can be connoted as mystification of reality where ideal society hides behind it an unequal, unjust and exploited society. As these books are constructed to be used in government sector schools where most of the children belonging to lower class family. The setting in almost every image is of village life, in Sindhi language books mostly. These visual representations depict a very beautiful life of the citizens. The family of the lower class is seemed to be living a happy and satisfied life. But in reality, it is the lower class which is most burdened, exploited and is in devastated conditions. One cannot say that life of villages is completely bashed, but these images show only one side of reality which is beautiful, happy and peaceful. On the other side, there is hunger, poverty, illiteracy, oppression and hard labor; the more prominent side of reality, is excluded from the representations. The choice of these images over the other possible one reflects the sociolinguist factors that are working behind it and speaks a lot about the culture that is promoted through these textbooks.

The state, of course, does not include the facts about the existing conditions in the textbooks no matter how much true they are, just to give the message of "everything is alright" to our younger generation. In this way, the reality is not only omitted but is also masqueraded under the wrong representations. Its constraints the possibility of knowing the truth and strive for social change. However, these actions make the students understand the truth presented to them in textbooks as ultimate truth and consider the existent conditions as natural. Michel Foucault (1980) believes that, discursive practices are characterized by the definition of a legitimate perspective for the agent of knowledge a delimitation of a field of objects, and the 
fixing of norms for the elaboration of concepts and theories. Hence schools play a significant role in cultural reproduction of class relations in society. Mystified image of the infrastructure of the Pakistani state is portrayed in Textbooks through pictures. The denotational aspects of an image make it seem natural. Like advertisement industries which hide the reality in order to justify the reasons for buying their product. The state has culture industry, which determines the standard norms legitimizing the dominant culture. The Pakistani state is also hiding all the inequalities and social and ethical exploitations by giving only the positive side of everything. The state forms culture industries that work in favor of the dominant group. It determines the consciousness of the population, according to the desire of powerful group, by developing standard products that are made to be followed by the population. It attempts at making the population to develop needs and wishes that is not against the state. Power is exercised by controlling the boundaries in which they think so that they are even unaware of their fact of being oppressed. They believe that the way they act and do things on their own free will. This type of education system addresses the need of only industrialization and economic uprising, but it snatches the real meaning of freedom, liberty and individualization. This mystification leads to transformation of bourgeois culture to universal nature.

\section{Conclusion}

The ideologies emerged from the image analysis above are fundamental to the process of state formation in Pakistan. These ideas provide a framework in which nationalism is constructed as the ideological basis for the nation and the realities of class division is disguised. Through these representations, Pakistan is defined as a state where all people-regardless of different ethnicity, culture, language, religion and social class lives in a homogeneous national community and leads a prosperous life. Textbooks privilege the state above anything. All the unevenness and exploitation of powerful group over powerless is legitimate by mystifying reality in textbooks. It can be said that the selection and organization of knowledge in schools are an ideological process that serves the interest of powerful classes and social groups. The study reflects that the images used in language textbooks are not only representations, but they reflect the ideologies that the state like to inculcate in upcoming generations. The images in textbooks do not depict the reality, but it gives a falsified image about reality that manipulates the students' thinking process. However, in today's modern world, the purpose of education is more enslavement than intellectual enlightenment: doing ethnic cleansing and concealment of class antagonism. Power is having its hold on knowledge in this society. In order to liberate the knowledge, we first have to liberate our system from this hegemonic control which will eventually lead to unbiased knowledge. Students must be exposed to all types of knowledge from various dimensions so that their knowledge must be based on truth and rational understanding. The thinking as repercussion from such biased content is more conservative, narrow mind and partial, that could be easily radicalized in any aspect. This is an effort to unfold the ideological loaded nature of images used in the curriculum at the school level. The study is limited to data collected from primary level books used in government schools. Further study can also be conducted with books used in higher level and implementing this research attempt at a broader level will yield sufficient results in terms of ideologies that are being promoted and strategies used for social 
relations reproduction through education in any society.

\section{References}

Althusser, L. (1970). Ideology and Ideological State Apparatuses. Lenin and Philosophy and other Essays. (B. Brewster, Trans.). (pp. 127-186). New York: Monthly Review Press.

Aftab, K. A. (1994). Ethnicity and education in nation building in Pakistan. Lahore, Pakistan, Vanguard publisher.

Apple, M. (2004). Ideology and Curriculum (3rd ed.). New York: Routledge Falmer.

Apple, M. (2000). Cultural politics and the text, chap. 9, (pp. 42-60). Official Knowledge (2nd ed.). London: Routledge,

Barthes, R. (1964). The Rhetoric of the Image (pp. 152-163). Image Music Text. Retrieved from https://faculty.georgetown.edu/irvinem/theory/Barthes-Rhetoric-of-the-image- ex.pdf

Bourdieu, P., \& Passeron, J. C. (1990). Reproduction in Education, Society and Culture (R. Nice Trans.) London: Sage Publications.

Bouzida, F. (2014). The Semiological analysis in media studies: Roland barthes approach. Published in proceedings of SOCIOINT14- International Conference on Social Sciences and Humanities, Istanbul, Turkey

Bureau of statistics planning and development department, Government of Sindh (2017, June), School education and statistics Sindh 2015- 16, Retrieved from http://sindhbos.gov.pk/wp-content/uploads/2017/01/School-Education-Statistics-2015-16.pdf

Chomsky, N. (1996). The Culture of Fear in Javier Giraldo, Colombia: The Genocidal Democracy, Common Courage Press, July 1996, https://doi.org/10.1080/13623699.2010.520952

Crawford, K. (2000). Researching the Ideological and Political Role of the History Textbook Issues and Methods, International Journal of History Learning, Teaching and Research, Vol. 1, No. 1 .

Creswell, J. W. (2012). Educational research: Planning, conducting and evaluating quantitative and qualitative research (4th ed.). Pearson Merrill Prentice Hall.

Fitsumbirhan, S. (2006). Representation of power relations in Ethiopian newspaper front page photographs: A semiotic analysis. Master's thesis, Addis Ababa University Graduate School of Journalism and Communication.

Foucault, M. (1980). Power/Knowledge Selected Interviews and Other Writings 1972-1977, Edited by Colin Gordon. New York: Pantheon Books.

Foucault, M. (1976). The History of Sexuality: The Will to Knowledge, volume: 1 (R. Huxley Trans.) London, Penguin.

Foucault, M. (1984). The Foucault reader. edited by Paul Rabinow, New York, Pantheon 
books.

Freire, P. (1970). Pedagogy of the Oppressed, 30th Anniversary Edition. New York: Continuum.

Gramsci, A. (Ed.). (1999). Selections from the prison notebooks. In Q. Hoare, \& G. N. Smith (Trans.). London, Lawrence \& Wishart.

Jat, A. R. L., Pathan. H., \& Shah, S. W. (2018). Representation of National Heroes in English Language Textbooks Taught at Government Higher Secondary Schools of Sindh, Pakistan. Microthink Journal of Education and Linguistics Research, 4(2). https://doi.org/10.5296/elr.v4i2.13612

Krishnan, M. (2015, October 22). Rewriting textbooks in India, a hidden agenda? Made for minds, Retrieved from http://p.dw.com/p/1GsUy

Kükürt, R, O. (2016). Semiology and a semiological reading of power myths in education. Educational Sciences: Theory \& Practice, 16(6), 2167-2191 https://doi.org/10.12738/estp.2016.6.2105

Nayyar, A, H., \& Salim, A. (2003). The subtle subversion: A report on curriculum and textbooks in Pakistan. Report of the project A Civil Society Initiative in Curricula $\backslash$ and Textbooks Reform. Sustainable Development Policy Institute, Islamabad. Retrieved from https://www.sdpi.org/publications/files/State\%20of\%20Curr\&TextBooks.pdf

Saussure, F. (1986). Course in general linguistics (3rd ed.). (R. Harris, Trans.). Chicago: Open Court Publishing Company. (Original work published in 1972).

Shruti, J. (2017, June 16). Rajasthan Textbooks Revised to Glorify Modi Government. The Wire. $\quad$ Retrieved from https://thewire.in/147887/rajasthan-textbooks-revised-glorify-modi-government/

Yaqian, W. (2012). Defining the Pakistani nation in history education: an examination of Pakistan studies textbooks. Master's thesis, National University of Singapore. Retrieved from https://scholarbank.nus.edu.sg/bitstream/10635/35848/1/WangYQ.pdf

Zaidi, M, A. (2010). Polarization of Social Studies in Textbooks in Pakistan, Pakistan institute for peace studies: Knowledge for peace. https://doi.org/10.1080/09585176.2011.550770

Zinn, H. (2016). on Democratic education, USA New York: Routledge publishers Taylor and Francis group.

Zinn, H. (1990). The politics of history (2nd ed.). Chicago, University of Illinois press. 


\section{I Macrothink}

\section{Appendices}

Appendix 1: Photograph of a school child from a village in Jaccobabad Sindh province, Pakistan.

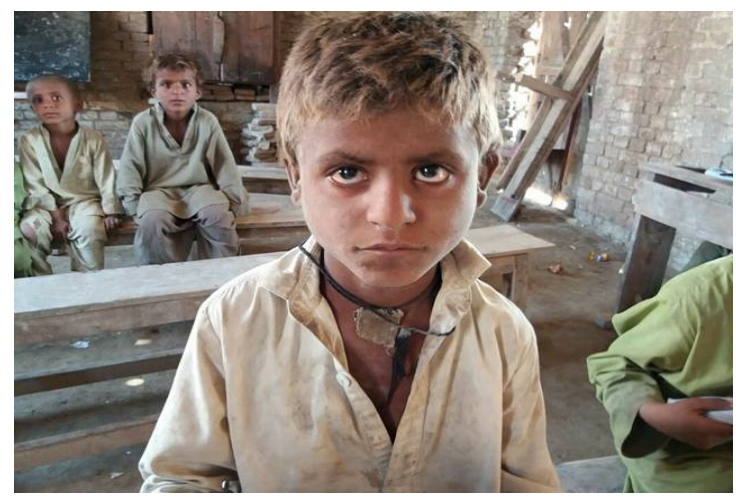

Appendix 2: Images of professions from different textbooks

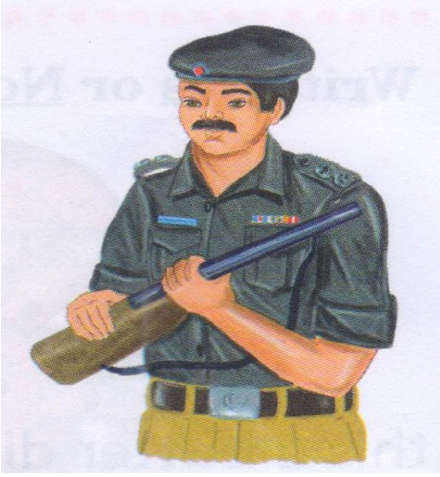

Figure 1

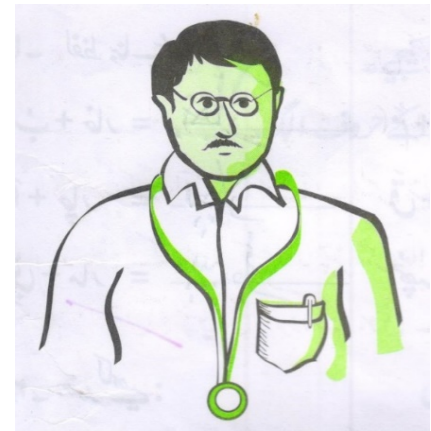

Figure 3

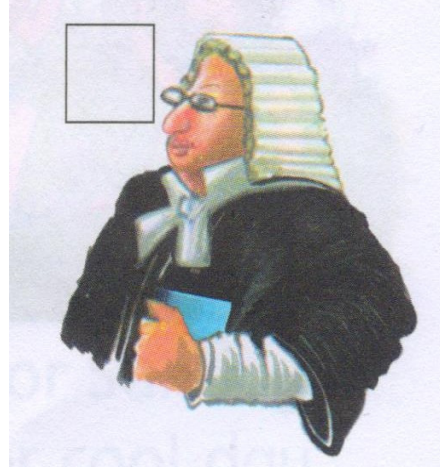

Figure 2

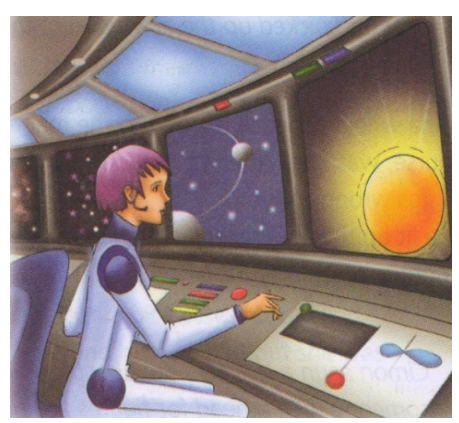

Figure 4

Source: Textbooks used in private schools; Fig B-1 (Literacy: An Interactive English Course, Introductory Book, Sunrise publication, page 50), Fig B-2 (Literacy, An interactive English course, Introductory book, page 66), Fig B-3 (Giada Urdu Ka Gulistan for Class 2. Oxford 


\section{Macrothink

Books, page 24), Fig B-4 (Oxford Modern English Book 6, Unit 12: Three Millennia, page

\section{Copyright Disclaimer}

Copyright reserved by the author(s).

This article is an open-access article distributed under the terms and conditions of the Creative Commons Attribution license (http://creativecommons.org/licenses/by/3.0/). 